\title{
The Tonkolili Iron Occurrence of Sierrra Leone: A Petrological Enigma?*
}

\author{
K. Dzigbodi-Adjimah and D. Nana Asamoah
}

Dzigbodi-Adjimah, K. and Nana Asamoah, D., (2009), “The Tonkolili Iron Occurrence of Sierrra Leone: A Petrological Enigma?", Ghana Mining Journal, Vol. 11, pp. 19 - 30.

\begin{abstract}
This paper endeavours to resolve, by petrological and mineralogical interrogations, the apparent puzzle being caused by the different names and classifications that have been assigned to the Tonkolili iron occurrence of Sierra Leone by different authors. The mineralogy and petrography of drill core samples of iron occurrences from Tonkolili district of Sierra Leone are used to investigate the type of iron deposit, its environment of formation and classification.

Three main rock types that host the Fe mineralisation have been identified as amphibolites, tuffs and mafic volcanic rocks. The amphibolites which crop out and are mapped on the surface are underlain by tuffs. Two types of tuffs were identified, namely as rhyolitic and crystal tuffs. The mafic volcanic rocks lie underneath the tuffs. The Fe mineralisations occur as bands and lenses in the tuff and are encountered from depths of 120 to $160 \mathrm{~m}$ in the drill holes.

The Fe mineralisations which are mainly of Precambrian age are chemical sediments, contain about $55 \% \mathrm{Fe}$ and occur as mappable bands and lenses that have ironstone layers defining their top and bottom and thus satisfy Kimberly (1978)'s classification as "iron formation".

It is therefore the conclusion of this paper that with the realisation that the primary Fe mineral is magnetite rather than haematite and since there is an intimate association between the volcanic rocks and the Fe mineralisations, the Tonkolili Fe deposits can be classified as an Algoma type of Banded Iron Formation according to the classifications of James (1954) and definition of Cannon et al., (1986).
\end{abstract}

\section{Introduction}

Precambrian $\mathrm{Fe}$ occurrences have been described in the northeast-trending ranges of Sula Mountains at Mankani, Yanka and Kailahun in the Tonkolili district of Sierra Leone (Macfarlane et al., 1981; Morel, 1979; Umeji, 1983). Two major Fe horizons with over 5.1 billion tonnes of ore at over 30 $\%$ Fe (Anon., 2009) have been estimated at Simbili (2.5 billion tonnes@30.4\% Fe) and Numbara (2.1 billion tonnes@30.2\% Fe) at Tonkolili (Fig. 1) making them the third largest magnetite ore deposit in the world. Earlier Macfarlane et al. (1981), Morel (1979) and Umeji (1983) had estimated over 100 million tonnes of $\mathrm{Fe}$ ore with $55 \% \mathrm{Fe}$ at the two locations. The Fe occurrences belong to the Matoto Formation of the Marampa Group of the Kambui Supergroup (Macfarlane et al., 1981). "Banded ironstones", of Liberian age, have also been reported on Katabai, Kotowu and Matindia Hills in the Loko Group at the top of the greenstone-belt succession at Sula-Kangari and Nimini (Morel, 1979; Umeji, 1983).

These iron occurrences of the Matoto Formation form an important unit in the volcano-sedimentary greenstone Basement Complex of Sierra Leone. They occur as sedimentary sequences commonly as lenses of titaniferous magnetite interbedded with garnet and hypersthene gneisses or quartzmagnetite/hematite gneisses. They range from a few hundred metres to several kilometres in length and from 30 to $100 \mathrm{~m}$ in thickness. The Fe lenses are enclosed in a metasedimentary unit mainly consisting of turbiditic metagreywacke, psammite and pellite, with intercalations of chert, quartzite, conglomerate and amphibolite schist.

The iron occurrences with the enclosing rocks have been affected by various grades of regional dynamothermal metamorphism ranging westwards from greenschist to granulite facies (Allen, 1969, Macfarlane et al., 1981). It is contested whether the metamorphism is all progressive or partly retrograde (Hurley et al., 1971; Macfarlane et al., 1981).

The mineralogy of these Fe occurrences appears not to have been studied in detail: whilst the Tonkolili occurrences are described as hematite orebody (Macfarlane et al., 1981), that of Marampa is variously referred to as a magnetite deposit by some and hematite deposit by others (Anon., 2008). Also different authors have variously referred to the iron occurrences by different names.

\footnotetext{
* Manuscript received April 23, 2009

Revised version accepted November 12, 2009
} 


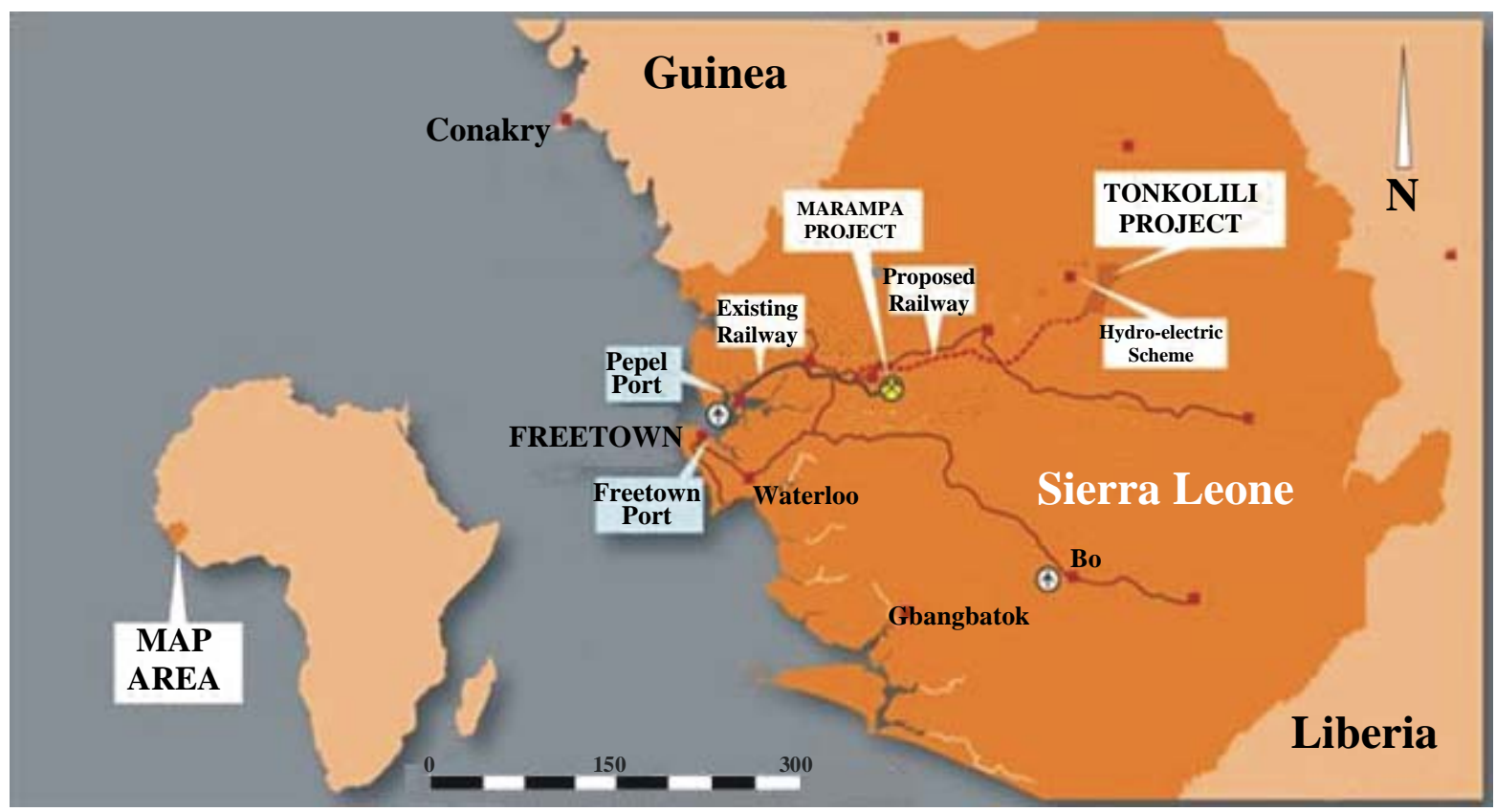

Fig. 1 Map of Sierra Leone showing the Locations of Marampa and Tonkolili

Examples of conflicting classification of these iron occurrences are as follows:

- Poole (1971) referred to them as "Banded ironstone",

- Rollinson (1978) as "ironstone",

- Morel (1979) and Umeji (1983) as "Banded Iron Formations or BIFs",

- Milesi et al., (1989) as "itabirites", and

- Macfarlane et al. (1981) as "lateritic or ferruginous oxides".

The mineralogy of iron deposits is largely controlled by the environment of formation (e.g. lateritic $\mathrm{Fe}$ ores of the Rio Tinto type result from oxidation and supergene activity whereas BIFs, like the Algoma and Superior Fe deposits of North America, are typically chemical sediments (James, 1954) whilst the tintaniferous-magnetite $\mathrm{Fe}$ ores of Kiruna, Sweden are typically of magmatic origin (Bateman, 1950). It will therefore be a mineralogical enigma if all the above iron deposit-types coexist in the same Archaean greenstone belt of the Sierra Leone.

This paper therefore looks at the mineralogy and petrography of the Tonkolili Fe occurrences (the most extensively developed $\mathrm{Fe}$ mineralisation in the Sierra Leone) with the objective of classifying the Sierra Leonean Fe occurrences as a contribution towards understanding their genesis to serve as a guide for further exploration and development of similar deposits in the West African Craton.

\section{Geological Setting}

\subsection{Regional}

Sierra Leone is underlain by rocks of two major tectonostratigraphic units (Fig. 2). The eastern unit is part of the stable Precambrian West African Craton and consists of high-grade metamorphic rocks and granitic gneisses. The western unit contains the elements of an orogenic belt named the Rokelides and was deformed during the PanAfrican tectenothermal event, about $550 \mathrm{Ma}$ ago (Morel, 1979). A 20-40 km wide coastal strip is made up of Pleistocene to Recent sediments known as the Bullon Group (Williams, 1978; 1988).

Archaean rocks are well developed in the eastern half and partly in the west of Sierra Leone, constituting the Kenema-Man domain, which outcrops also in neighbouring Guinea, Liberia and in southwestern Ivory Coast. These rock units are characterised by relic zones of supracrustal rocks occurring as greenstone belts, mainly forming synclinal structures amid granitic gneisses and autochithonous and parautothonus granitoids. In western Sierra Leone, the greenstone belts are large up to 130 $\mathrm{km}$ long with thick successions (up to $6.5 \mathrm{~km}$ ), and metamorphosed to amphibolites grade. Banded ironstone (BIF) is a minor lithological character. In southeastern Sierra Leone, the schist relics are smaller (up to $40 \mathrm{~km}$ long) with thinner stratigraphic successions, in which banded iron formations are dominant. The metamorphic grade is variable, both within belts and between belts, from greenschist to granulite facies. The type area of the Kenema assemblage in central Sierra Leone comprises granites and acid gneisses, granulite facies rocks and greenstone belts of schistose sediments and volcanics. In the northeast of the country, two separate suites of a greenstone belt have been distinguished in the Kenema assemblage. The older suite is represented by the Loko Group of the Ka- 


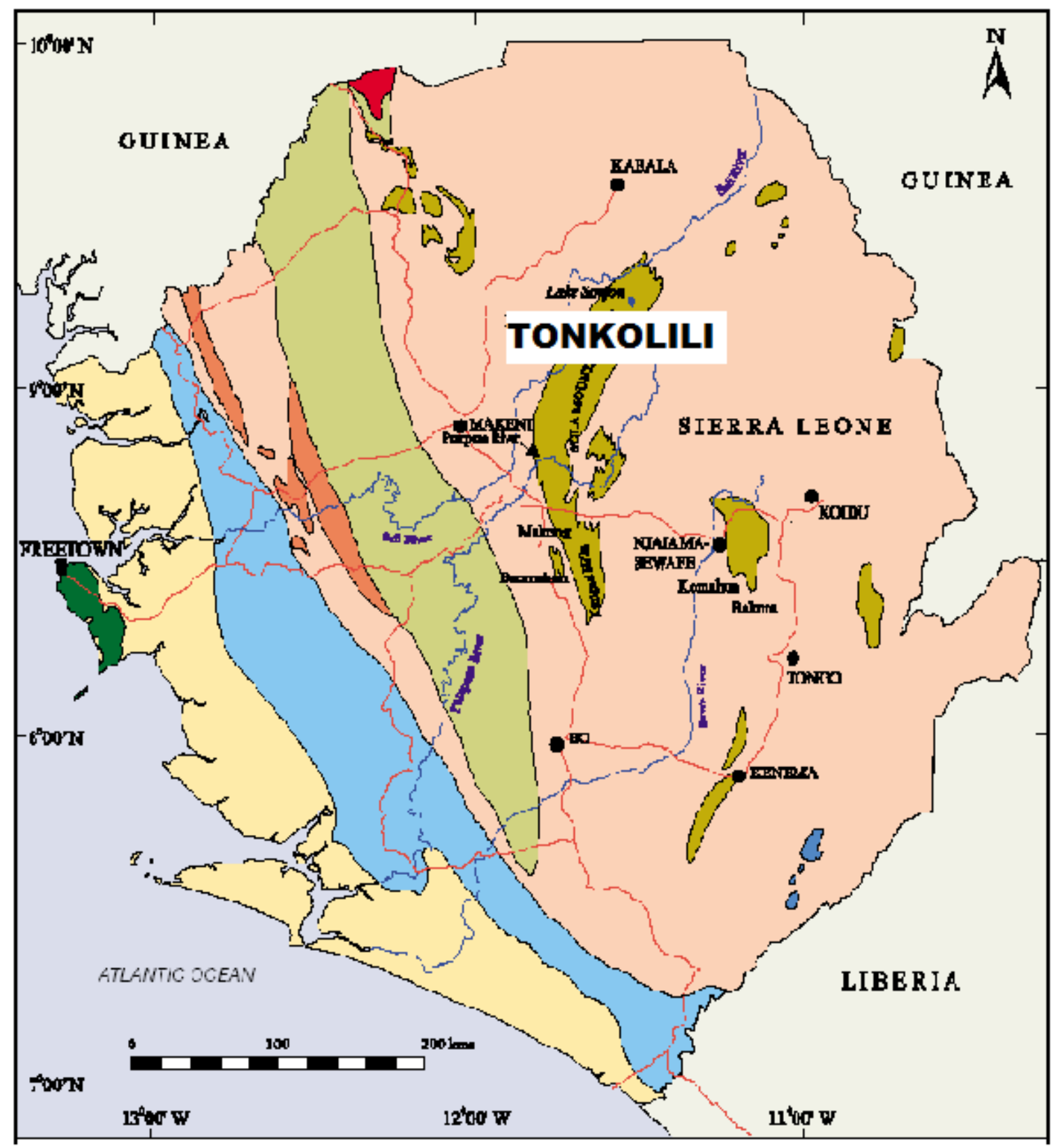

Fig. 2 Map of Sierra Leone showing the Location of Tonkolili and the Local Geology (Anon., 2003)

mokwie area and is composed of amphibolites with subordinate serpentinites, quartzites and banded ironstones. It was deformed and metamorphosed during Leonean tectonothermal event dated at about 2,960 Ma (Macfarlane et al., 1981).

The younger suite, termed the Kambui Supergroup, consists of a lower volcanic formation, which includes massive pillow lavas of basic (amphibolitic) and ultrabasic (serpentinite) composition, overlain by tuffs, psammites, pelites and banded ironstones. These rocks were deformed and metamorphosed during the Liberian tectothermal event dated at about 2,750 Ma. The Rokelide Orogenic belt that was deformed during the PanAfrican tectothermal event about $550 \mathrm{Ma}$ ago ex- tends some $600 \mathrm{~km}$ from western Guinea along coastal Sierra Leone into Liberia. Kasila Group represents a linear belt, more than $30 \mathrm{~km}$ wide of high grade supracrustal rocks of Archaean age, which were reworked during the Pan-African Orogeny. It consists mostly of felsic gneisses in the granulite facies, charnockites, garnet hornblende gneiss and garnet-plagioclase gneiss, and in places hornblendite and pyroxenite.

To the east of the Kasila Group, low-grade supracrustal rocks of the recumbently folded Marampa Group overlie granitic terrains and are probably in fault contact with Rokel River strata. The Marampa Group contains ironstone, mafic to felsic volcanic rocks and derived volcanogenic 
sediments that are similar to greenstone belt lithologies seen to the east within the Kenema Assemblage. The rocks of the Marampa Group were originally formed about 2,100 Ma ago, their PanAfrican deformation was dated at about $560 \mathrm{Ma}$ (Morel, 1979; Wright et al., 1985). The Rokel River Group comprises the easternmost domain in the Rokelide orogenic belt in Sierra Leone. It occupies a belt some $30 \mathrm{~km}$ wide and $225 \mathrm{~km}$ long and is subdivided into 10 different units (Culver et al., 1991) which are named as follows: Tibal Member, Taban Member, Dodo Member Teye Formation, Mabole Formation I, Taia Formatiion I, Kasewe Hills Formtion, Taia Formation 2 and Mabole Formation 2. Generally, these units are comprised of marls, quartzites sandstone and volcanic rocks. There are no direct geochronological data available for the Rokel River Group, but its basal glacigenic deposits can be correlated with similar strata in Senegal and Mauritania which are generally accepted to be Neoproterozoic in age. The peninsula of Freetown is made up of Mesozoic basic intrusives (Morel, 1979).

\subsection{The Tonkolili and Marampa Iron Occur- rences}

African Minerals is working the two iron ore projects at Tonkolili and Marampa (Fig. 1). The Tonkolili iron ore project, situated in the Sula Mountains Greenstone Belt, approximately $150 \mathrm{~km}$ from the Pepel deep water port near Freetown, located within the Company's EXPL 05/06 licence, is an advanced project undergoing resource definition drilling and exploration of extensions of the mineralised zone identified to date (Anon., 2008). The Marampa Mine was previously owned by the $\mathrm{Si}$ erra Leone Development Company ('Delco') and was in operation for over 30 years using the Pepel deep water port and railway to export iron ore before its closure in the 1970s.

\section{Petrography}

Three rock types that are identified (from drill cores from the Tonkolili deposit) to host the Fe mineralisation include amphibolites, schists and tuffs. The lithology from top to bottom is:

- Amphibolite (outcrops at the surface);

- Rhyolitic and crystal tuffs from depth of 80 $\mathrm{m}$ to $200 \mathrm{~m}$; and

- Mafic volcanic rocks now metamorphosed to amphibole-biotite schists (below $200 \mathrm{~m}$ )

The detail petrographic description of the rocks vis -à-vis the Fe mineralisation is as follows:

\subsection{Amphibolite}

In hand specimen, Tonkollili amphibolite is a dark green and foliated rock which, in thin section, is composed almost entirely of amphiboles mainly ferro-actinolite and grunerite together with specks of iron oxide (Fig. 3). Quartz is rare and plagioclase absent. It is schistose and fine-grained. The rock is more of an amphibolite schist rather than amphibolite (senso stricto) as it does not have plagioclase and quartz, which are essential minerals for amphibolites and gneisses.

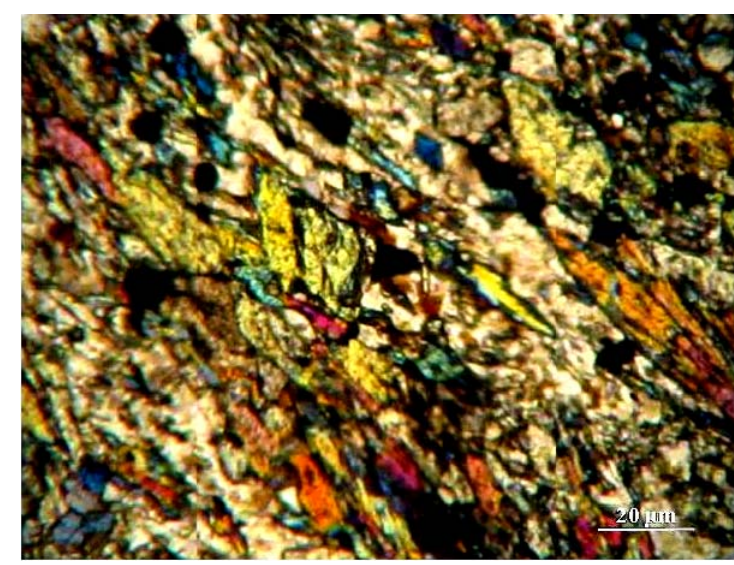

Fig. 3 A Photomicrograph of a Thin Section of Amphibolite from Tonkolili (Cross polarised light)

\subsection{The Tuffs}

The main minerals of the tuffs include cherty quartz and biotite; amphibole may or may not be present. The tuffs contain shards of angular to rounded rock fragments and sanidine and range from fine-grained to coarse-grained varieties. The biotite is horny and resinous whilst the quartz is cloudy and unclear with rod-like microstructures. Two types of tuffs were identified, namely as; Rhyolitic and Crystal Tuffs. The Rhyolitic tuffs are characterised by a predominantly siliceous composition of more than $70 \%$ cherty quartz and subordinate (less than 5\%) amphibole crystals. The Crystal Tuff, on the other hand, has less than $70 \%$ quartz and more than $10 \%$ (crystals of amphibole).

\subsubsection{Rhyolitic Tuff}

This rock is a cream grey fined-grained rock obtained from a drill core at depth $118.9 \mathrm{~m}$ located at the central portion of the prospect.

It is fine-grained, grey volcanic tuff with amphibole and feldspars. In hand specimen, the sample is grey in colour and very fine-grained, massive and non-foliated. In thin section, it is made up of anhedral quartz, bands of mica (mostly biotite) with laths and prisms of colourless to neutral (non pleochroic) amphiboles (mostly grunerite) which show strong birefringence under cross polars. The modal composition (visual estimation) is shown in Table 1. 
Table 1 Comparison of Modal Compositions (Vol. \%) of Tuffs

\begin{tabular}{|c|c|c|}
\hline & Rhyolitic tuff & Crystal tuff \\
\hline Quartz & $40-50$ & $60-70$ \\
\hline Biotite & $20-30$ & $20-25$ \\
\hline Grunerite & $10-20$ & $10-20$ \\
\hline Iron Oxides & & $5-10$ \\
\hline
\end{tabular}

The tuff is fine-grained and foliated with pyroclastic and metamorphic texture. It contains angular fragments and shards of sanidine. In the thin section, the rock is holocrystalline with flaky biotite

(measuring $15 \times 5 \mu \mathrm{m}$ ) and euhedral to subhedral amphibole crystals (60 $\mu \mathrm{m}$ in diameter) dispersed in a groundmass of anhedral quartz. Biotite occurs either as single flakes or in bands and appears to an older mineral in the rock paragenesis as the flakes are somewhat aligned in parallel bands (Fig. 4B). Amphibole is granular and appears to have developed, most presumably during metamorphism, across the mica bands. The sample has a semblance of a tuff as the quartz looks like recrystallised chert: the edges are sutured suggesting annealing whilst the presence of tiny mica and ampbibole flakes that appear to be entrapped or embayed in the quartz (Fig. 4B) tends to suggest a glassy (vitric) origin. The presence of fragments or shards of a colourless, weakly birefriengent mineral that bears all the semblance of sanidine (Fig. $4 \mathrm{~B})$ confirms that the rock is a tuff.

\subsubsection{Crystal Tuff}

In hand specimen, the crystal tuff is grey in colour, fine-grained and looks like a silicified tuff. In thin section, it is made up of quartz, biotite and amphiboles with a modal composition as shown in Table 1. The quartz is anhedral, cloudy and dusty; amphiboles are mostly euhedral and lath-like while biotite is scaly and not fibrous. There is no groundmass or cementing material. Texturally the rock is coarse-grained with euhedral amphiboles but anhedral quartz (Fig. 5).

\subsection{The Schists}

The schists are similar in mineralogy and texture to the tuffs. The main differences are that the schists are less quartzose (about $30 \%$ compared to over $50 \%$ quartz of the tuffs) and also their foliation; whilst the tuffs show simple foliation (Figs. 4 $\&, 5)$. The schists have more flaky minerals and display schistose texture with fibrous micas and amphiboles flowing around granular quartz and feldspar crystals (Figs. 6, $7 \& 8$ ). There are various gradations among the schists depending mainly on variations in mineralogy whilst biotite and quartz remain the main minerals, some have grunerite others not, some have hornblende others plagioclase whilst others have none. Since plagioclase and quartz are essential minerals for amphibolites and gneisses the presence or absence of these two were used to subdivide the schistose rocks into schists and amphibolites. The schists have much higher biotite content than the amphibolites. Generally three types of schists are recognized. These are:

- Grunerite-Quartz-biotite schist

- Quartz-biotite schist, and

- Amphibole-biotite schist

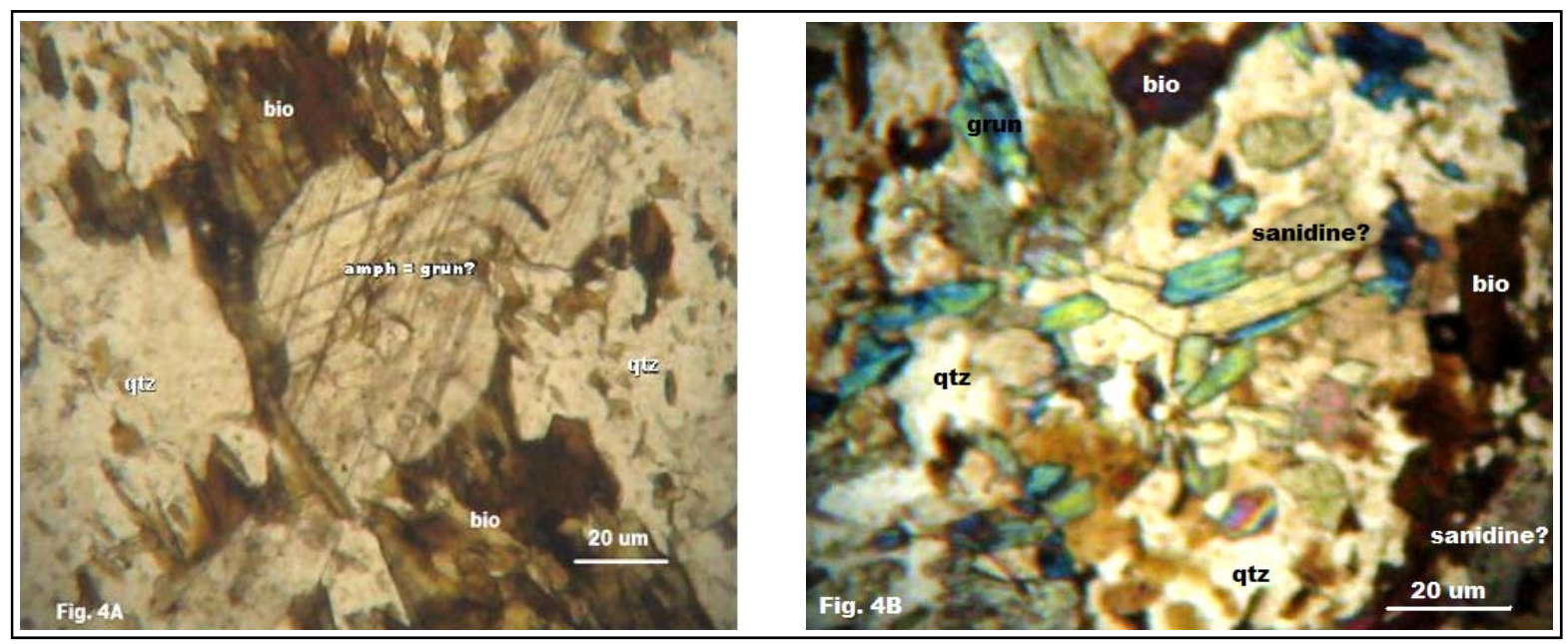

Figs. 4A \& 4B Photomicrographs of Thin Sections of Rhyolitic Tuff. (A = Plane polarised light) showing a holocrystalline and foliated rock made up of bands of biotite, anhedral quartz and colourless amphibole. $\quad(B=$ Cross polarised light) showing grunerite crystals randomly dispersed in a matrix of anhedral quartz with a biotite band (at left of picture) lying parallel in the plane of foliation. 
Table 2 The Modal Composition of Grunerite Quartz-Biotite Schist

\begin{tabular}{|c|c|}
\hline Minerals & Composition (Vol. \%) \\
\hline Quartz & $30-40$ \\
\hline Biotite & $25-30$ \\
\hline Grunerite & $15-20$ \\
\hline Ferro-actinolite & $5-10$ \\
\hline
\end{tabular}

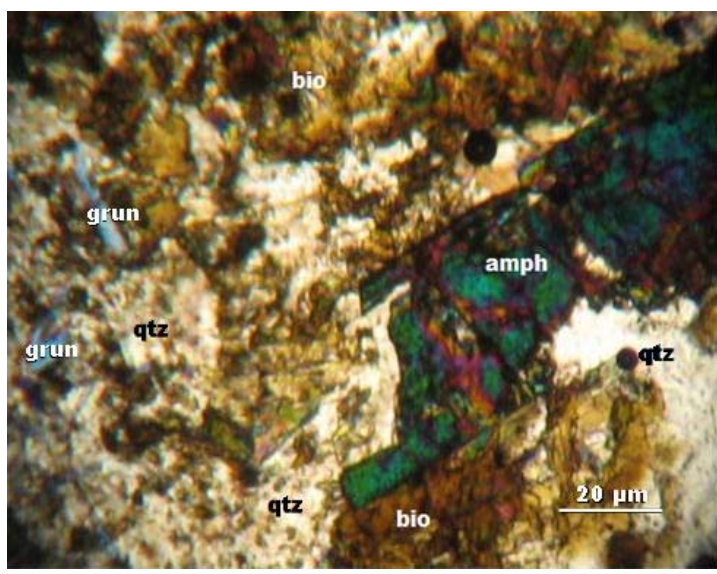

Fig. 5 A Photomicrograph of a Thin Section of Crystal Tuff (Cross polarised light)

\subsubsection{Grunerite Quartz-Biotite Schist}

In hand specimen, the sample is greyish, very finegrained (much finer than the tuff). It is generally massive and structureless. Ferro-actinoliteGrunerite-Biotite Schist is very similar to the rhyolitic tuff in mineral composition and texture. The only differences being in the presence of ferroactinolite (which was not observed in the rhyolitic tuff) and a much finer grain-size. In thin section, it is found to be made up of biotite, amphiboles (grunerite and ferro-actinolite) with quartz. The biotite exits mostly as tiny flakes that are randomly oriented, the grunerite is generally prismatic and non pleochroic whilst the ferro-actinolite tends to be fibrous and pleochroic in shades of brown and green and was distinguished from hornblende by its rather small extinction angle of $\approx 14^{\circ}$. The quartz is granular and anhedral. The visual composition is shown in Table 2 .

\subsubsection{Quartz-Biotite Schists}

Quartz biotite schists are grey, medium-grained rocks that have acicular amphibole, quartz and feldspar and resemble amphibolite in handspecimen. In thick section, however, they were observed to be composed of quartz and biotite and laths of plagioclase with interspersed hornblende and grunerite. The rock is sheared and foliated.

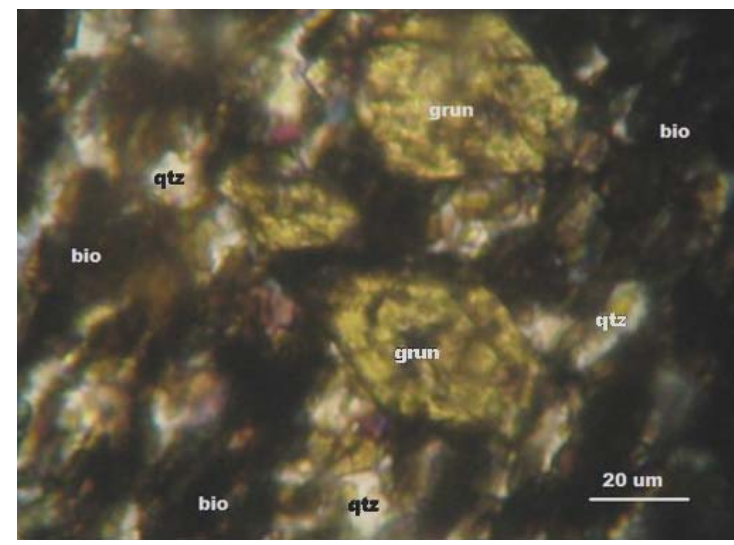

Fig. 6 A Photomicrograph of Grunerite Quartz -Biotite Schist showing Euhedral Rhombic Grunerite Crystals developing porphyroblastically across the plane of foliation (Plane polarised light).

Plagioclase appears to have been rotated whilst the quartz and biotite crystals are perfectly aligned with their long axes lying parallel to direction of foliation (Fig. 7A) indicating their premetamorphic origin. The amphibole porphyroblasts on the other hand, tend to grow across the foliation bands.

\subsubsection{Amphibole-Biotite Schists}

This rock is a dark grey medium-grained rock obtained from a drill core at depth $201.00 \mathrm{~m}$. It is fine grained, grey finely foliated mafic volcanic rock with aligned amphibole and feldspars as shown in Figs $8 \mathrm{~A} \& 8 \mathrm{~B}$.

\section{The Fe Mineralisation}

The Tonkolili Fe ore shows alternating dark and light-coloured banding which a characteristic feature of Banded Iron Formations (BIFs). The banding may be observed megascopically but in thin section, band widths range from 5 to $30 \mu \mathrm{m}$ averaging $20 \mu \mathrm{m}$ as seen in Fig. 9. The dark bands are magnetite-rich whilst, the light -coloured bands are made up almost exclusively of quartz. In some samples, the banding is amphibole-rich versus quartz-rich with magnetite sparsely distributed across both bands (Fig. 12A). In some amphibolite samples magnetite is sparsely distributed and may constitute an iron mineralisation of economic potential.

On the basis of mineralogy and texture, three types of BIF were identified in the present investigation and these may be described as:

- Quartz-Magnetite BIFs

- Quartz-Grunerite-Magnetite BIF

- (Amphibolite) or Grunerite Quartz-Biotite Schist with magnetite 


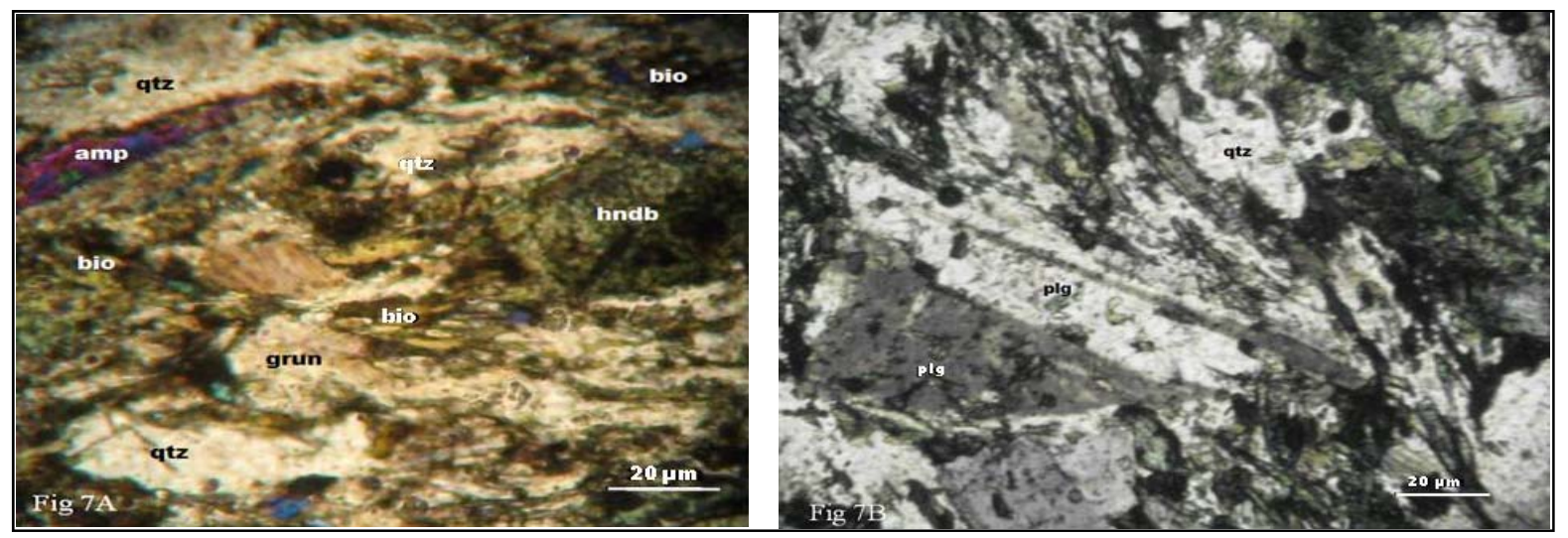

Figs. 7A \& 7B A Photomicrographs of a Thin Section of Quartz-biotite Schist (a metamorphosed mafic volcanic rock) showing (A) a rhombic section of hornblende (green) (B) a rotated lath of plagioclase surrounded by flakes of biotite. (Cross polarised light).

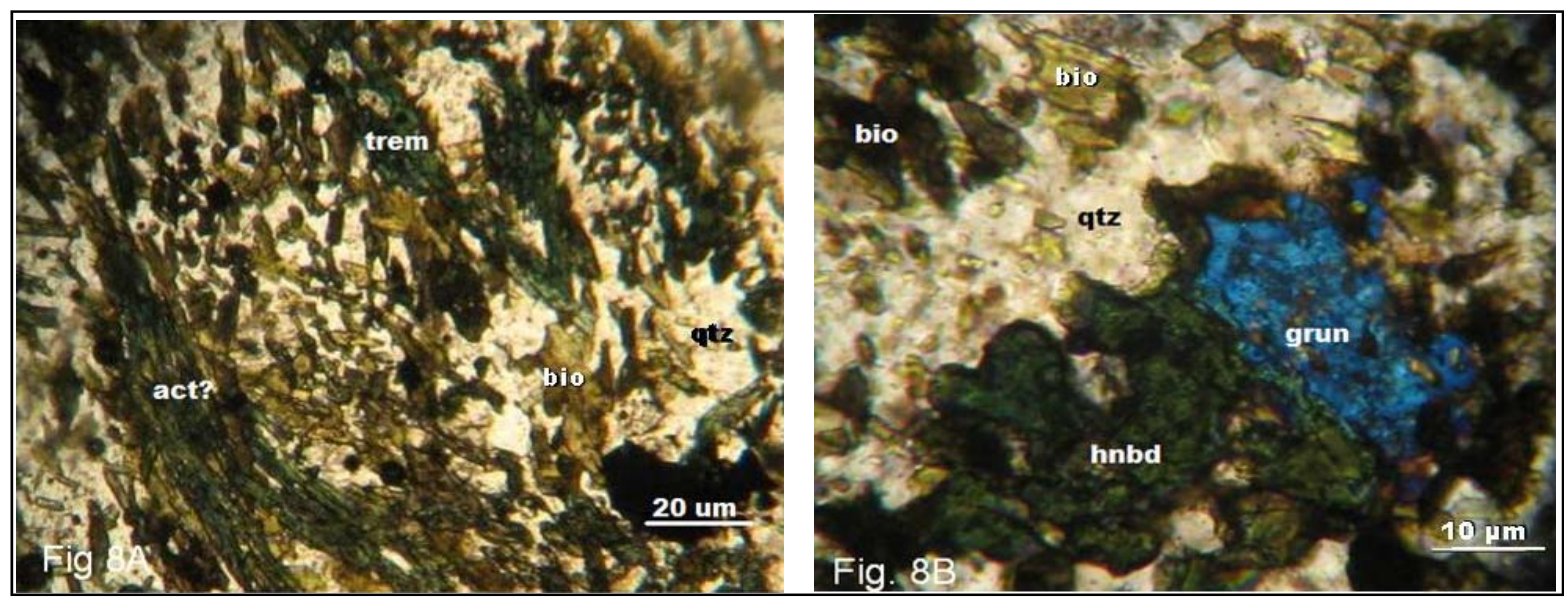

Fig. 8A \& 8B (A) Photomicrograph of a Thin Section of Ferro-actinolite-grunerite-biotite Schist (B) Grunerite Quartz-Biotite Schist (Cross polars)

\subsection{Quartz-Magnetite BIFs}

These rocks are banded and composed of the usual dark and light-coloured bands. The dark-coloured bands, consists mainly of sub-rounded to subangular grains iron oxide with quartz as the binding or interstitial material as seen in Fig. 10. In these bands the Fe exhibits what appears as emulsion texture (Fig. 11A) and appears as if it has exsolved out of the enclosing quartz grains (Fig 11A). In the lighter coloured bands, however, magnetite content decreases with a corresponding increase in pyrite content (Fig. 11B).

\subsection{Quartz-Grunerite-Magnetite BIF}

These rocks are banded like the quartz- magnetite BIFs but they are poorer in magnetite content whilst richer in the amphibole (grunerite). The bands are made up of alternating layers of amphiboles on one hand and quartz with magnetite on the other hand as seen in Fig. 12A. Even in the lighter coloured quartz-magnetite rich bands, mag- netite content is sparse and not as heavy as seen in the quartz magnetite samples (Fig. 12B).

\subsection{Amphibolite with Magnetite}

The amphibolites are quartz- and biotite-rich rocks that are interspersed with hornblende and grunerite with no feldspar. They are sheared and foliated with both quartz and biotite crystals perfectly aligned with their long axes lying parallel to direction of foliation indicating their pre-metamorphic origin. The iron ore minerals in the rock are pyrite and magnetite. The pyrite is anhedral and granoblastic. It also carries inclusions of rock material and appears to be growing across foliation thus indicating a syn-metamorphic origin (Fig. 13). The magnetite grains on the other hand are much smaller and are corroded and occur as relics. They are aligned parallel to the foliation planes of the rock suggesting a pre-metamorphic origin. 


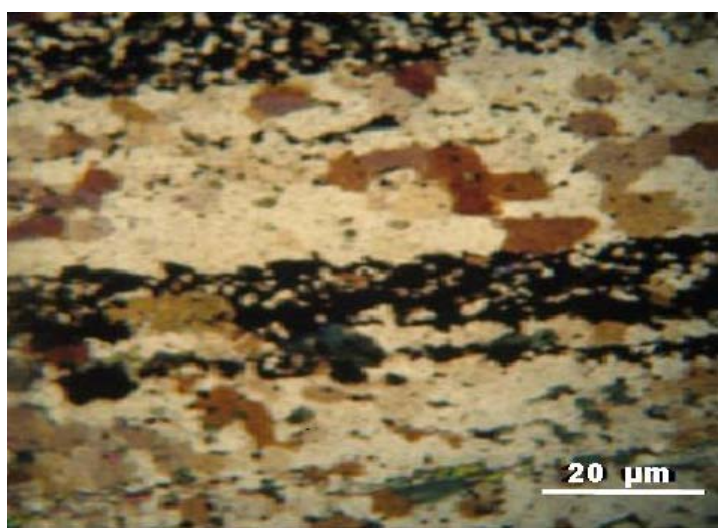

Fig. 9 A Photomicrograph of a Thin Section of Tonkolili Fe ore in pane polarised light showing alternate quartz-rich and Ferich banding.

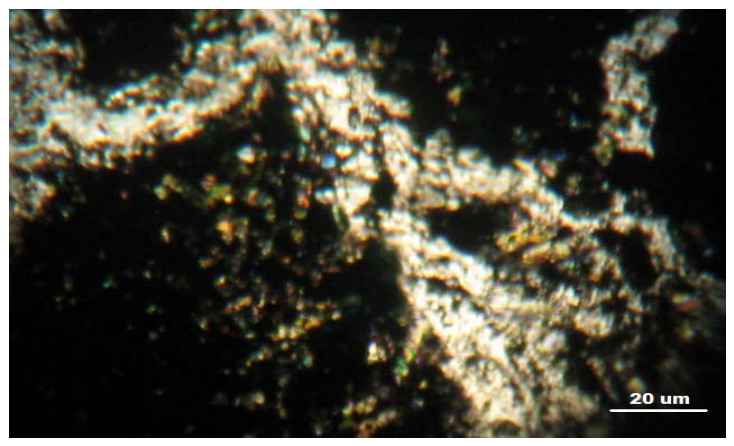

Fig. 10 Photomicrograph of a Thin Section of Quartz-Magnetite BIF showing alternate light (quartz-rich) and dark (Fe-rich) bands (Cross polars)

\section{Discussion}

\subsection{Geological Setting and Petrological Associa- tions}

From the geological setting, it could be seen that the 'ironstones' of Sierra Leone occur predominantly in the Archaean rocks of Marampa and Sula Groups of Kambui Supergroup as discontinuous horizons or layers in the sedimentary units is either close to or on top of volcanic units. At Tonkolili, the foremost beds are pebbly and locally conglomeratic and pass into fine-grained tuffaceous and clastic sediments that host the discontinuous ironstone bands within the Tonkolili Formation and at Marampa, discontinuous haematite-quartzite horizons form an integral part of the sedimentary Rotokolou Formation. The geological setting is thus that of sedimentary iron horizons associated with volcanic suites.

From the petrographic point of view, the host felsic and mafic volcanic rocks are observed to have been metamorphosed to amphibolite facies with grunerite the most pervasive amphibole.

- The tuffs are fine-grained and composed mostly of grunerite, plagioclase feldspar, and volcanic material. Biotite may or may not be present.

- The mafic volcanic rocks which are predominantly of medium-grained have been converted to schists and amphibolites and presently consist of grunerite-quartz-biotite and ferro-actinolite-grunerite-biotite schists and amphibolites.

- The Fe mineralisation, senso stricto, consists of lenses or bands of quartz-magnetite, grunerite-magnetite and quartz-gruneritemagnetite interbedded with the rhyolitic tuffs commonly but not necessarily containing layers of chert. It is encountered in drillholes from depths of 100 to $170 \mathrm{~m}$.

From the granoblastic textures it could be said that the $\mathrm{Fe}$ mineralisation may have resulted from metamorphic processes.

\subsection{Polish Section Observations}

From the polish section observations, it is seen that banding and distribution of magnetite in the Tonkilili ore are of two types. In the quartzmagnetite ores (Fig. 10) and quartz- gruneritemagnetite ores (Fig. 11) banding consists of alternating light-coloured quartz (cherty)-rich bands and dark coloured iron-oxide (magnetite)-rich bands with grunerite sparsely distributed in both bands (Figs. $9 \&$ 12A). In the amphibolite with magnetite ores, however, amphiboles and biotite are the main minerals whilst the magnetite is sparely distributed throughout the rock. From the economic point of view, the Quartz-magnetite ores appear to be the higher grade ore as they carry the densest concentration of $\mathrm{Fe}$ oxide.

Magnetite is the main Fe mineral, but hematite and pyrite are quite common especially in the low grade amphibolites and schists. Magnetite appears as a primary ore mineral since it displays emulsion texture which may be interpreted as crystallisation from melt signifying a magmatic (possibly volcanic) origin. It is also heavily corroded and either aligned parallel to the foliation planes or is banded indicating a pre-metamorphic origin. The haematite might possibly be an oxidation product of primary magnetite. The pyrite, on the other hand, is generally porphyroblastic and grows across rock foliation buttressing the fact that it is of a younger generation and possibly syn-tectonic.

\subsection{Classification}

In the attempt to classify the Sierra Leonean Fe occurrences, it is necessary to outline their essen- 


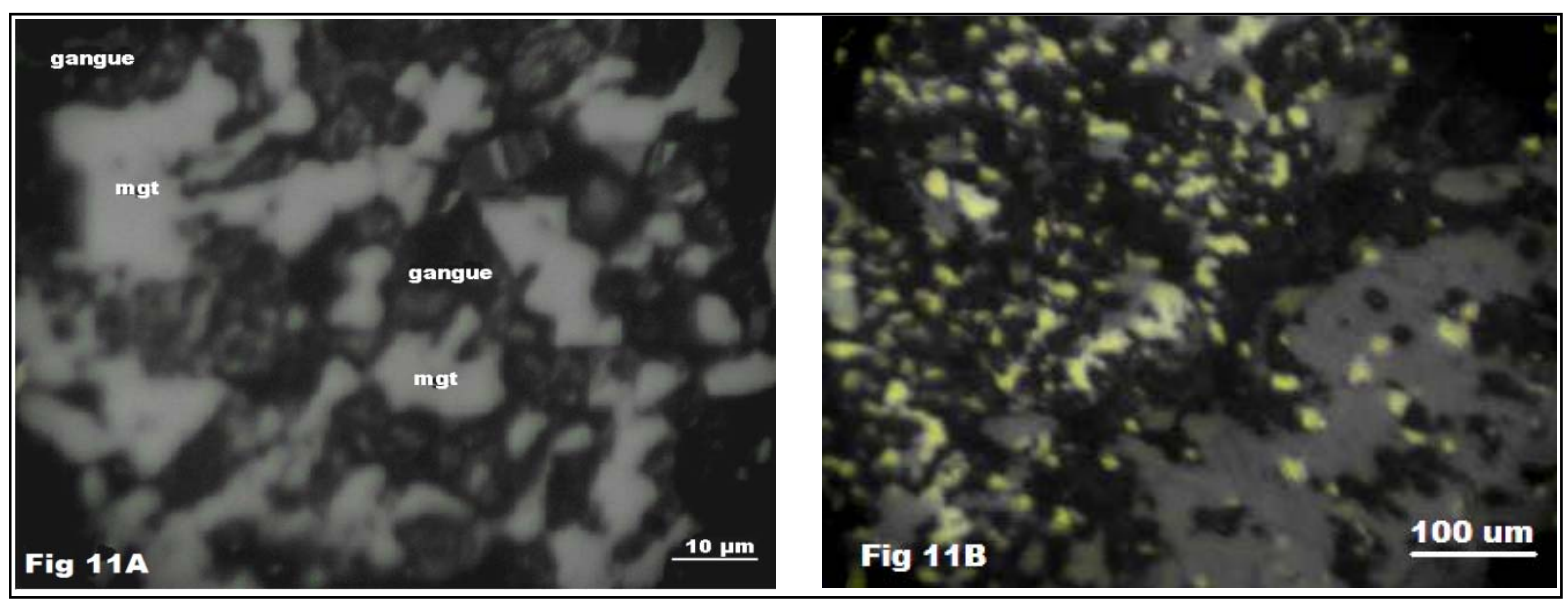

Fig. 11A \& 11B Photomicrographs of (Polish Sections a Quartz-Magnetite BIF) showing (A) emulsion texture (B) a denser distribution of magnetite in the dark bands The creamy yellow mineral is pyrite.

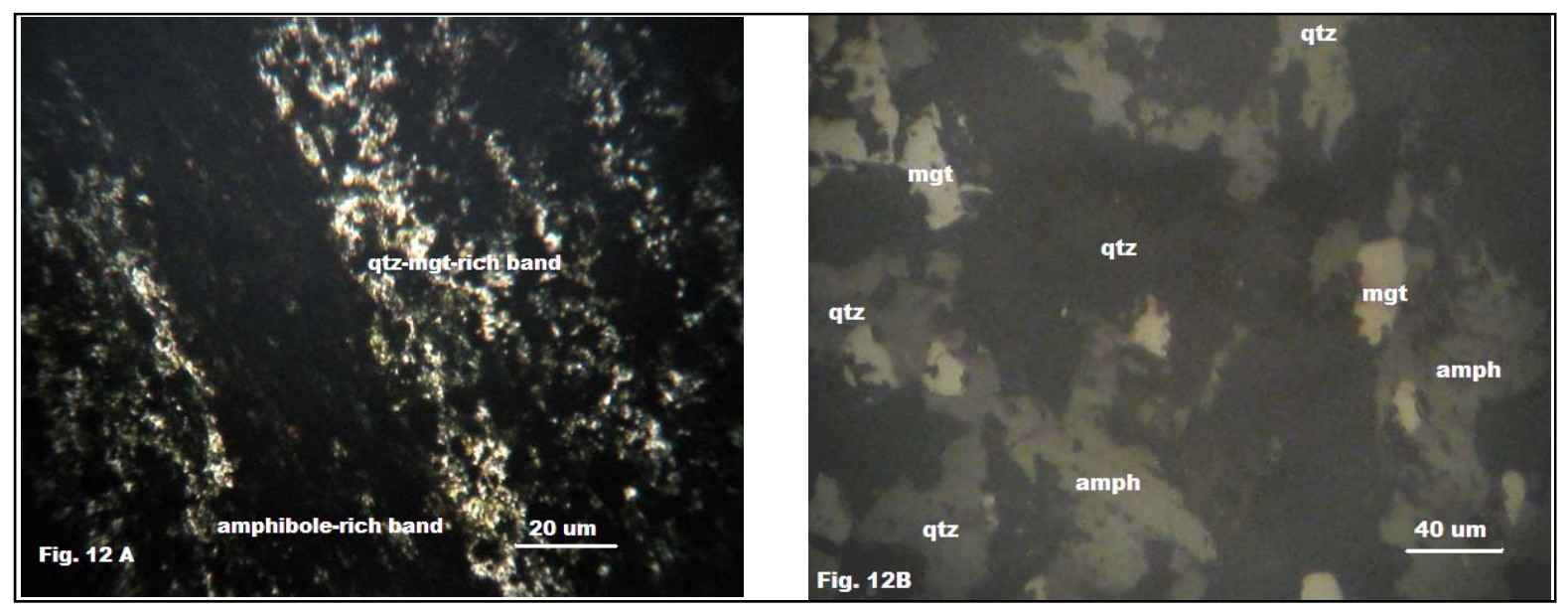

Figs. 12A \& 12B Photomicrographs of two different textures of the Quartz-Grunerite-Magnetite BIF (A = Thin Section, plane polarised light showing banded texture. (B = Polish Section, plane polarised light showing disseminated texture)

tial features vis-à-vis the salient points of various classifications of Iron deposits.

\subsubsection{Fe Ore Classes}

Iron Ore mineralisations may be classified into the following 4 classes and range in impotance from:

1. Sedimentary Iron ores like hematite ores of Lake Superior and magnetite ores of Algoma regions of North America and from AlsanceLorraine Minnete ores of Central Europe to the limonite-siderite Clinton ores of New York;

2. Magmatic Iron deposits e.g. magnetite and titaniferous magnetite mineralisations of Kiruna and Taberg Sweden: Iron Mountain Wyo., and Andirondacks, New York;

3. Contact-metasomatic and replacement Iron deposits e.g. Magnetite and specularite mineralsations of Iron Springs, Utah or Lyon mountain New York; to

4. Lateritic ores resulting from oxidation and supergene activity as found in the limonite and hematite ores of Rio Tinto and Bilbao, Spain and Morocco, North Africa.

By far the most important source of iron is from Sedimentary deposits of which Banded Iron Formations or BIFs are the most impotant. James (1954) defined Banded Iron Formation (BIF) as "a chemical sediment, typically thin-bedded or laminated, containing $15 \%$ or more iron of sedimentary origin, commoonly but not necessarily containing layers of chert". And Kimberly (1978) proposed that "iron formation" be used to describe a mappable rock unit or package dominated by ironstone (chemical sediments with more than $15 \% \mathrm{Fe}$ ) and with ironstone layers defining its top and bottom. Since the Tonkolili occurrence is described as a $\mathrm{BIF}$, it is assumed that it satisfies the above re- 


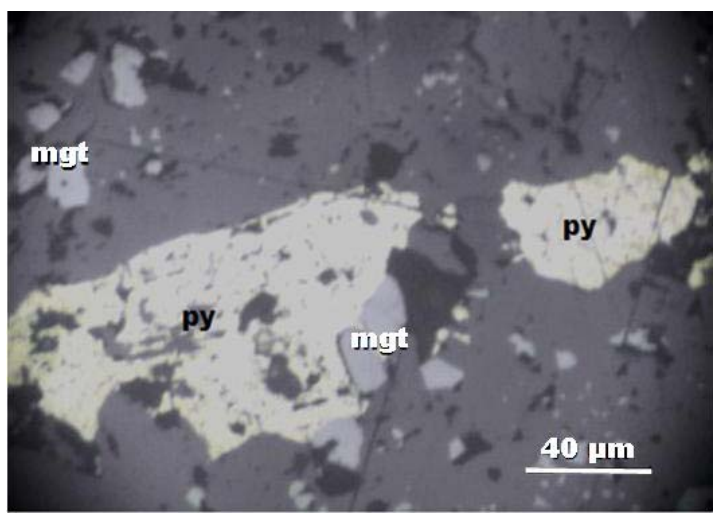

Fig. 13 A Photomicrograph of a Polish Section of Grunerite-Quartz-Biotite Schist showing pyrite and magnetite mineralisation. (Polish section Plane Polarised Light)

quirements. If the distinction between the two broad classes of BIFs, namely; that magnetite-rich Algoma types are of Archaean age and specifically relatable to submarine volcanic processes whilst hematite-rich Superior types are of early Proterozoic age and may not necessarily include volcanic input, then the Tonkolili iron ore mineralisation bears all the semblances of an Algoma type of BIF.

\subsubsection{Deposit Type}

From their geological setting and petrographic associations, the Fe deposits at Tonkolili area do not appear to be layered magmatic Fe deposits. Neither could they be classified as Bog or Marsh iron occurrences or ironstones. This is because they do not occur in mafic and ultramafic igneous rocks and are not associated with anorthosite and ilmenite bands. They also are not segregated like observed in layered mafic Fe ores of Kiruna, Sweden (Parák, 1991). Though of sedimentary origin, their petrographic association, mineralogy and constitution are distinctly different from the Bog or Marsh Fe ore deposits as they are not associated with swampy or lacustrine rocks and goethite the major iron mineral in Bog deposits has not been associated with them. The presence of chert coupled with the absence of glauconite and the Archaean age of the Tonkolili Fe occurrences also distinct them from ironstones which are dominantly glauconitic and essentially postPrecambrian.

Since the Sierra Leonean Fe occurrences are sedimentary and occur as cherty horizons in close association with rhyolitic rocks, they may be described as chemical sediments that are associated with volcanic rocks. They also form mappable rock units with ironstone layers defining their tops and bottoms and have an average Fe content of more than $55 \%$ Fe (Farlick et al., (1989). The Tonkolili Fe deposits thus satisfy James (1954)'s criterion of a thin bedded or laminated chemical iron layers of sedimentary origin with more than $15 \% \mathrm{Fe}$ content and may thus be regarded as "Banded" iron deposits. They are also characterised by distinct sedimentary horizons that are mappable units with ironstone layers defining its top and bottom and thus satisfy Kimberley's (1978) classifications of "Iron Formation". The Sierra Leonean Fe occurrence at Tonkolili may, thus be appropriately be regarded as "Banded Iron Formation" or "BIF".

\subsubsection{Algoma vrs Superior Type BIFs}

Since there are two types of Banded Iron Formations, namely; the Algoma and the Superior types it is important to see to which of these groups the Sierra Leone Fe occurrences belong. Generally the Algoma type BIFs may be distinguished from Superior type BIFs as shown in the Table 3.

\section{The probable location of the Tonkolili BIF}

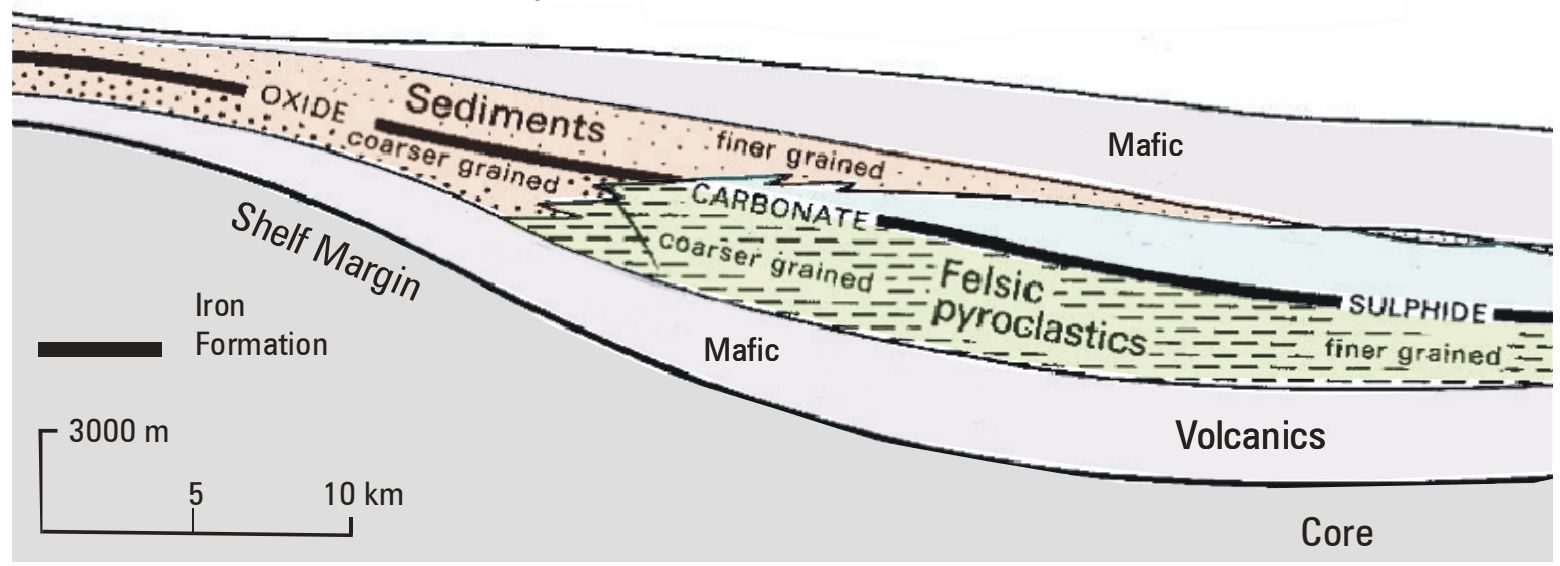

Fig. 14: A stratigraphic section showing the probable location and depositional facies of the Tonkolili BIF in a sedimentary basin (After Goodwin, 1973). 
Table 3: Distinctions between Algoma and Superior types of BIF.

\begin{tabular}{|c|c|c|}
\hline FEATURE & ALGOMA TYPE & SUPERIOR TYPES \\
\hline Size & $\begin{array}{l}\text { Usually small } \\
\text { deposits measuring } \\
\text { a few metres up to a } \\
\text { maximum of } 10 \mathrm{~km} \\
\text { strike }\end{array}$ & $\begin{array}{l}\text { Larger deposits } \\
\text { measuring up to } 100 \\
\text { km or more along } \\
\text { strike }\end{array}$ \\
\hline Age & Archaean & $\begin{array}{l}\text { Precambrian mostly } \\
\text { Proterozoic }\end{array}$ \\
\hline Mineralogy & $\begin{array}{l}\text { Magnetite-rich }+ \\
\text { chert }\end{array}$ & $\begin{array}{l}\text { Haematite- goethite- } \\
\text { rich + jasper }\end{array}$ \\
\hline $\begin{array}{l}\text { Geological } \\
\text { setting }\end{array}$ & $\begin{array}{l}\text { Volcanic Island } \\
\text { Arcs \& Ocean } \\
\text { Floor Spreading } \\
\text { Ridges, parts of } \\
\text { volcanic rich } \\
\text { greenstone belts }\end{array}$ & Continental margins \\
\hline Texture & $\begin{array}{l}\text { Laminated and } \\
\text { streaky }\end{array}$ & Oolitic and granular \\
\hline $\begin{array}{l}\text { Origin of } \\
\text { the Iron }\end{array}$ & $\begin{array}{l}\text { Volcanic } \\
\text { Exhalative origin } \\
\text { Sub-volcanic } \\
\text { volcanic processes. }\end{array}$ & $\begin{array}{l}\text { Mostly terrigeneuos } \\
\text { processes derived } \\
\text { from landmasses by } \\
\text { weathering, } \\
\text { transportation, } \\
\text { erosion, precipitation. }\end{array}$ \\
\hline
\end{tabular}

Tonkolili Fe deposits are BIFs that are:

- Dominantly magnetite-rich, rather than hematite rich.

- Typically devoid of oolitic and granular textures and is rather streaky and mostly laminated.

- Archaean rather than Proterozoic and

- Occur with pyroclastic and meta-volcanic rocks that suggest a volcanic exhalative origin to the iron

They display more of the characteristics of the Algoma type than Superior type BIFs (Farlick et al., 1989). The Tonkolili Fe occurrence may thus be described as an Algoma type of Banded Iron Formation.

\subsection{Probable Depositional Environment}

The observed felsic pyroclastic-and-maficvolcanic association with typically oxide facies that has no carbonates or sulphides and mediumgrained nature of the rocks at the Tonkolili tend to suggest that the probable depositional environment of the formation of the Tonkolili Fe mineralisation is that of sedimentary facies of BIF formed between fine-grained and coarse-grained oxide facies (15 to $20 \mathrm{~km}$ from shoreline) as shown in Fig.14.

\section{Conclusions}

From the present investigation it may be concluded that:

- The Tonkolili iron mineralisation is a Banded Iron Formation of the Algoma type BIF. It is a Quartz-Magnetite BIF that is closely associated with felsic pyroclastic and mafic volcanic rocks.

- The mineralisation is made up of very finegrained magnetite (measuring 10-40 $\mu \mathrm{m}$ in diameter). It is typically devoid of oolitic and granular textures and is rather streaky and mostly laminated.

- The iron is probably of volcanic exhalative origin. The petrographic association of felsic pyroclastics with mafic volcanics puts the sedimentary facies of depositional environment at between 15 to $20 \mathrm{~km}$ from shoreline between the oxide and carbonate facies.

\section{References}

Allen, P. M., (1969), The Geology of parts of an orogenic belt in Western Sierra Leone, West Africa Geo. Rdsch 58(2), pp. 588-620.

Anon. (2009), Tonkolili iron ore www.africanminerals.com/Corporate 09/12/09 5 pp.

Anon. (2008), www.african-minerals.com/ Corporate/Operations/

Tonkolili_Iron_Ore_Project assessed 06/05/09 $3 \mathrm{pp}$.

Anon. (2003), www.johnbirchall-economist.com/ sreport 4.doc assessed 06/05/09 5 pp.

Bateman, A. M., (1950), Economic Mineral Deposits. New York: Wiley 916 pp.

Cannon, W. F., (1986), Descriptive model of Algoma Fe, in Cox, D.P., and Singer, D.A., eds., Mineral deposit models: U.S. Geological Survey Bulletin 1693, 198 pp.

Culver, S. T., Williams, H., R. and Bull, P. A., 1980, Late Precambrian glacial deposits from rokelide fold belt, Sierra Leone. Paleogeography, Paleoclimatology, Paleoecology, Vol. 30, pp. 65-81.

Evans, A. M., (1992), Ore Deposit Geology and Industrial Minerals: An Introduction $\left(3^{\text {rd }}\right.$ Edition). Blackwell Science. pp. 253-257.

Farlick, P. W., Barret, T. J., Jarvis, K. E., Jarvis, L, Schieders, B. R. and Kemp, R. V. (1989), Sulphide facies iron formation at the Archaean Morley occurrence, Western Ontario: contrasts with hydrothermal oceanic deposits. Can Mineral. Vol. 27; pp. 601-616.

Goodwin, A. M. (1973), Archaean iron formations and tectonic basins of the Canadian Shield. Economic Geology. Vol 68; pp. 915933. 
Hurley, P. M., Leo, G. W., and Fairbairn, N. W., (1971), Liberian Age Province (about 2700 m.y and adjacent provinces in Liberia and Sierra Leone. Bulletin of Geological Society of America. Vol. 82, pp. 3483-3490.

James, H. L. (1954), Sedimentary facies of iron formation. Econ. Geol. Vol. 49. pp. 235-293.

Kimberly, M. M. (1978): Paleoevironmental classification of iron formation Econ Geol. Vol. 73. pp. 215-229.

Macfarlane, A., Crow, M. J., Arthurs, J. W., Wilkinson, A. F., Aucott., J. W., (1981), The geology and mineral resources of northern Sierra Leone, Overseas Memoir 7, Institute of Geological Sciences, Natural Research Council, London. Her Majestys Stationary Office 96 pp.

Milesi, J. P., Ledru, P., Domanget A., Johan V., Diallo M., (1989), Lower Proterozoic succession Senegal \& Mali (West Africa). Position of sediment hosted $\mathrm{Au}$ and deposits of Loulo area and significance in terms of crustal evolution, $28^{\text {th }}$ Int. Geo. Cong., Washington, USA.2-3 pp, 433-434.

Morel, S. W., (1979), Geology and Mineral Resources of Sierra Leone. Economic Geology Nov 1979 vol. 74 no 7 pp. 1563-1576.

Parák, T., (1991), Volcanogenic sedimentary-rockrelated metallogenesis in the Kiruna-Skellefte belt of northern Sweden, Econ Geol. Monogr.Vol 18. pp. 20-50.

Poole, M. J. (1971), Report on sheet 19. Rep. Geo. Surv. Sierra Leone, Unpublished.

Rollinson, H. R., (1978), Zonation of Supracrustal relics in Archaean Basement of Eastern Sierra Leone. Precambrian Research Liberian, Guine and Ivory Coast. NA LTRE,. G. B., 272, no 5652, pp. 440-442.

Umeji, A. C., (1983), Archaean Greenstone Belts of Sierra Leone with Comments on the Stratigraphy and Metallogeny. Journal of African Earth Science 1 No 1 pp. 1-8.

Williams, H. R., (1978). The Archaean geology of Sierra Leone, Precambrian Research 6 pp. 251 -268 .

Williams, H. R., (1988), The Archaean Kasila Group of western Sierra Leone: Geology and relations with adjacent granite greenstone terrain, Precambrian Research 38 pp. 201-238.

Williams, H. R. and Culver, J. S. (1988), Structural terranes and their relationships in Sierra Leone, Journal of African Earth Sciences Vol. 7, Issue 2, pp. 473-477.

Wright, J. B., Hastings, D. A, Jones, W. B and Williams H. R., (1985), Geology and Mineral Resources of West Africa. Allen and Unwin, London, UK, 187 pp.

\section{Authors}

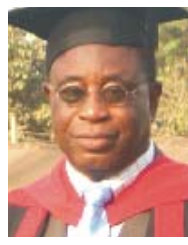

K. Dzigbodi-Adjimah is a Mining and Exploration Geologist who was educated at Technical University of Berlin - Dr. rer nat (Petrology) in 1987, University of Leicester in MSc (Mining Geology) - 1976 and University of Ghana for BSc Honours (Geology) in 1971. His research interests are in gold and manganese occurrence in Precambrian terrains especially the Birimian of West Africa. Currently he is an Associate Professor of Geology and Vice Principal of the Western University College of KNUST, Tarkwa.

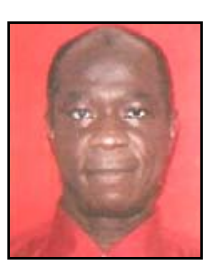

D. Asamoah (a.k.a Nana Asamoah) holds an MSc degree in Mining Geology from the Moscow Friendship University, Russia. Before joining the University of Mines and Technology (UMaT), Tarkwa in 1996, he worked with the Geological Survey of Ghana as a Senior Geologist and Regional Director of the Eastern Region. Presently, he is a Lecturer in the Geological Engineering Department at UMaT. He actively researches in gold in the Birimian terrain of West Africa. 